\title{
EFFECT OF REST SYSTEMS DURING SPAWNING SEASON ON THE SPAWNING EFFICIENCY OF NILE TILAPIA IN COMMERCIAL HATCHERIES
}

\section{R. M. Abou-Zied}

\author{
Animal Production Department, Faculty of Agriculture, Fayoum University, Egypt \\ Corresponding author: abouzied2004@vahoo.com
}

\section{SUMMARY}

This experiment was conducted to compare the effect of two resting system for 15 days of broodstock (rest in hapas and rest in ponds) versus no-resting control treatment on 6 months larvae production and spawning synchrony of Nile tilapia Oreochromis niloticus stocked in 12 hapa with a water volume of $25 \mathrm{~m}^{3} / \mathrm{hapa}$ suspended in earthen pond, four hapa/treatment. Adult males and females with mean body weights of $140 \mathrm{~g}$ and $125.4 \mathrm{~g}$, were stocked at a rate of $120 \mathrm{fish} / \mathrm{hapa}$ with a male to female sex ratio of 1:3. Water temperature at 29 $\pm 1.0^{\circ} \mathrm{C}$ and salinity $2.4 \mathrm{ppt}$ were maintained throughout the experiment.

The results showed that broodstock in the rest system had higher seed production and spawning synchrony compared with those in no rest. The resting system resulted in an increase from 20.6 to $31.7 \%$ in larvae/female. The different spawning parameters of broodstock in the rest in hapa and rest in pond were higher than in the no rest (control).

Results suggested that broodstock resting strategy had a long-term improvement effect on larvae production and spawning synchrony, and resting all breeders in ponds was more profitable but faced a problem, its needed two pond more than hatchery pond which is not available in most hatcheries.

\section{Keywords: Nile tilapia, spawning performance, economic efficiency, broodstock resting}

\section{INTRODUCTION}

Tilapia hatcheries were widespread throughout Egypt, especially in the presence of fish farms, almost each large farm had a hatchery either commercial or produced fry needed (GAFRD. 2012). Fish production from aquaculture activities contributed $74 \%$ of the total fish production which amounted 1.305 million metric tons, and tilapia constituting $63.48 \%$ of them. The fisheries sector contributed $8.5 \%$ in national agriculture income. The exploited area in Fish farms in Fayoum Governorate was 2750 feddans besides 12 fish hatcheries (GAFRA, 2012).

Most use hapa-based production systems in earthen ponds using the methods developed in South East Asia for commercial production of Nile tilapia fry and fingerlings (Bhujel et al., 2001, 2007; Escover et al., 1987; Little and Hulata, 2000 and Little et al., 1995). Hapas in ponds are cheap to construct and more convenient to manage in commercial tilapia hatcheries (Bhujel, 2000).

Only a limited number of studies have highlighted the technical characteristics and economic performance of different commercial tilapia hatchery systems in Egypt (Abou-Zied and Ali, 2007; Eldokla et al., 2011 and Naiel et al., 2011).

Like other production, seed production stages gradually increased until it reached the highest level and then decreased until the season ends, which is estimated at around six months in Egypt for that, it is preferred to rest the broodstock during this period to restore its activity.
Conditioning of tilapia brood-stock requires maintaining males and females separately in different units, for a period of rest between spawning, at a high stocking density $2.5 \mathrm{~kg} / \mathrm{m}^{2}$ with good feeding regimes (Ambali, 1990). Exchange of both male and female brood-stock conditioned for 21 days resulted in a $16 \%$ increase in egg and fry production over a 105 days pawning period as compared to either no broodstock exchange or female only exchange (Lovshin and Ibrahim, 1988). Conditioning of females has been found to improve spawning synchrony and seed output. However, conditioning for more than 10 days had no advantage over shorter periods ( Little et al., 1993). Moreover, conditioning for 20 days resulted in $18 \%$ decrease in seed output per unit area per day (Little et al., 1993). This is possibly due to the reabsorption of well-developed ova in the ovary which starts after about a week if females do not spawn (Peters, 1983). Moreover, it has been found that conditioned females with conditioned males produce more eggs as well as spawning more frequently than only conditioned females and no conditioning males (Ambali, 1990 and Little et al., 1993). This is possibly due to the active roles of rested males in courtship. Moreover, fertilizing capacity of sperm sharply decreased from about $90 \%$ to $20 \%$ with increase in mating frequency (Rana, 1986) probably because of the production of immature spermatozoa. However, resting of males for long periods might have negative effects on sperm quality as spermatozoa are continuously produced and released into the lumen of the testis and the sperm quality declined with time after release. It 
seems that a short period 5-10 days of resting males, like females, might be optimum (Purdom, 1993).

Since broodstock exchanged faced a problem in implementation thus this research aimed to resting broodstock for 15 days once in spawning season to increase larvae production.

\section{MATERIALS AND METHODS}

This study was conducted in a commercial hatchery at Shakshouk province, Fayoum Governorate, Egypt, to evaluate the resting systems for Nile tilapia applied in other commercial hatcheries on the spawning efficiency. The experiment extended during the period from 20 April, 2014 to 16 October, 2014.

One thousand four hundred and forty brood-stock were equally divided on twelve hapa located in broodstock earthen pond. Each hapa has an area of 5 $\times 7 \mathrm{~m}$ with a water depth of $70 \mathrm{~cm}$. Three resting systems (treatments) were tested. Each system represented by four hapa (as replicates) as follows: System 1: broodstock continuous larvae production without stopping (no rest, control). System 2: broodstock rested in hapa for males alone and others for females at density of $20 \mathrm{fish} / \mathrm{m}^{3}$ for 15 days. System 3: broodstock rested in pond for males and females each other's alone at density of $20 \mathrm{fish} / \mathrm{m}^{3}$ for 15 days.

Nile tilapia, Oreochromis niloticus, male and female with mean body weights of $140 \mathrm{~g}$ (110-170 g) and $125.4 \mathrm{~g}(110-145 \mathrm{~g})$, respectively, were stocked at a density of $5 \mathrm{fish} / \mathrm{m}^{2}$ and at a sex ratio of 1:3 male to female (each hapa contains 120 broodstock, 90 females +30 males).

Broodstock in hapa were hand-fed with $3.0-\mathrm{mm}$ sinking pellets ( $30 \%$ crude protein) at a rate of $2.0 \%$ of fish body weight (Bhujel et al., 2007) two meals per day except the days of collecting of larvae, but during the resting period fed at a rate of $3 \%$ of body weight twice daily for 15 days. Larvae were collected from hapa every 5 days and were individually counted.

Diets used during the experiment were analyzed for their proximate composition in triplicates following the methods described by AOAC (1999). Water temperature, $\mathrm{pH}$, dissolved oxygen $\left(\mathrm{DO}_{2}\right)$, ammonia $\left(\mathrm{NH}_{3}-\mathrm{N}\right)$, nitrate and salinity throughout the experimental period were periodically measured in the morning and at noon by using centigrade thermometer, Orion digital pH meter model 201, oxygen meter, Cole Parmer model 5946, HACH test kit ammonia mid-range 0-3 $\mathrm{mg} / \mathrm{L}$ model NI-8, $\mathrm{HACH}$ test kit Nitrate/Nitrite model NI-12 and TDS apparatus, respectively.

\section{Statistical Analysis:}

Data were statistically analyzed using a one-way analysis of variance using SPSS (2007) version 16. Mean of treatments were compared by Duncan multiple range test when the differences were significant (Duncan, 1955).

\section{RESULTS AND DISCUSSIONS}

\section{Water quality:}

Table (1) showed the water quality parameters measured during the study in fish hapas. Mean values of water quality parameters were recorded as follows: DO $6.08 \pm 0.37 \mathrm{mg} / \mathrm{L}, \mathrm{pH} \quad 8.0 \pm 0.20$, temperature $29 \pm 0.75{ }^{\circ} \mathrm{C}, \mathrm{NH}_{3}-\mathrm{N} \quad 0.2 \pm 0.10 \mathrm{mg} / \mathrm{L}$ and salinity $1.4 \pm 0.08 \%$ respectively. These values were within the safe ranges and acceptable for the spawning and growth of tilapia as reported by Magid and Babiker (1975), Ross (2000), El-Sayed (2006) and El-Sherif and El-Feky (2008).

Table 1. Mean water quality parameters measured during the study

\begin{tabular}{lcccccc}
\hline Item & $\begin{array}{c}\mathbf{D O}_{\mathbf{2}}, \\
\mathbf{m g} / \mathbf{L}\end{array}$ & $\mathbf{p H}$ & $\begin{array}{c}\mathbf{T e m p .}, \\
{ }^{\circ} \mathbf{C}\end{array}$ & $\begin{array}{c}\mathbf{N H}_{\mathbf{3}}-\mathbf{N}, \\
\mathbf{m g} / \mathbf{L}\end{array}$ & $\begin{array}{c}\mathbf{N O}_{\mathbf{3}} \\
\mathbf{m g} / \mathbf{L}\end{array}$ & Salinity, \\
\hline First month & $6.23 \pm 0.25$ & $8.0 \pm 0.21$ & $28 \pm 0.80$ & 0.2 & 0 & $1.3 \pm 0.11$ \\
Second month & $6.10 \pm 0.36$ & 8.00 .20 & $29 \pm 0.80$ & 0.2 & 0 & $1.5 \pm 0.11$ \\
Third month & $6.05 \pm 0.24$ & 8.00 .20 & $30 \pm 0.81$ & 0.2 & 0 & $1.4 \pm 0.11$ \\
Forth month & $6.38 \pm 0.38$ & 8.00 .21 & $29 \pm 0.81$ & 0.2 & 0 & $1.5 \pm 0.13$ \\
Fifth month & $5.70 \pm 0.48$ & 8.00 .20 & $29 \pm 0.81$ & 0.2 & 0 & $1.5 \pm 0.10$ \\
Sixth month & $6.05 \pm 0.31$ & 8.00 .21 & $28 \pm 0.82$ & 0.2 & 0 & $1.4 \pm 0.11$ \\
Mean \pm S.E & $6.08 \pm 0.37$ & $8.0 \pm 0.20$ & $29 \pm 0.75$ & $0.2 \pm 0.10$ & 0 & $1.4 \pm 0.08$ \\
\hline
\end{tabular}

\section{Spawning efficiency before resting:}

Spawning performance of Nile tilapia $O$. niloticus under different broodstock resting schedules are presented in Table 2. The rest in hapa and in pond treatments had insignificant differences and the mean values were nearly equal for total larvae production per hapa (261000 and 268200, respectively) and without rest was 260550 larvae. Larvae number/females (2900 and 2980, respectively)and without rest being 2895; spawning interval (19.55 and 19.03, respectively) and was 19.59 for control.

These results were obtained because all treatments received the same conditions thus it is nearly similar in spawning parameters values. 
Table 2. Spawning efficiency of Nile tilapia brood before resting system (mean \pm S.E.)

\begin{tabular}{lccc}
\hline & \multicolumn{3}{c}{ Resting system } \\
\cline { 2 - 4 } & Without & In hapa & In pond \\
\hline Number of days & 105 & 105 & 105 \\
Total larvae weight/hapa, $\mathbf{g}$ & $2895 \pm 146.15$ & $2900 \pm 148.61$ & $2980 \pm 85.54$ \\
Total larvae number/hapa & $260550 \pm 13153$ & $261000 \pm 13374$ & $268200 \pm 7698$ \\
Larvae weight, g/hapa/month & $827 \pm 41.75$ & $829 \pm 42.46$ & $851 \pm 24.44$ \\
Larvae number/hapa/month & $74,443 \pm 3758$ & $74,571 \pm 3821$ & $76,629 \pm 2200$ \\
Larvae weight/female & $32.17 \pm 1.62$ & $32.22 \pm 1.65$ & $33.11 \pm 0.950$ \\
Larvae number/female & $2,895 \pm 146$ & $2,900 \pm 149$ & $2,980 \pm 86$ \\
Spawning intervals, day & $19.59 \pm 1.05$ & $19.55 \pm 1.07$ & $19.03 \pm 0.56$ \\
Frequency spawning/female & $5.36 \pm 0.27$ & $5.37 \pm 0.28$ & $5.52 \pm 0.16$ \\
\hline
\end{tabular}

Values in the same row with different superscripts are significantly different $(\mathrm{P} \leq 0.05)$

Average larvae weight/female approximately $6 \mathrm{~g}$ and average larvae number/g $=90$ larva

\section{Spawning efficiency after resting:}

Spawning performance of $O$. niloticus under different broodstock after resting schedules are presented in Table 3. Resting system in pond had the highest larvae weight/hapa, larvae number/hapa, larvae weight/hapa/month, larvae number/hapa/month, larvae weight/female, larvae number/female and frequency spawning/female being 1400, 126000, 700, 63000, 15.56, 1400 and 2.59, respectively and the best spawning intervals whereas the control (without) had the lowest estimates values. The rest in hapa and in pond treatments had significant differences and the mean values for total larvae production per hapa were increased by $(258$ and $325 \%$, respectively) than control (without resting). Larvae number/females; frequency of spawning had the same trend. In all parameters, resting broodstock in ponds were improved more than broodstock without rest (control) by approximately three times and quarter and broodstock rested in hapa improved by about two and half times than control.

The results appeared significantly improved for spawning performance with larvae collected from brood resting in pond and hapa than that collected directly from hapas without resting. This may be due to the active roles of rested males in courtship. It seems that a short period of 15 days of resting males, like females, might be optimum.

Table 3. Spawning efficiency of Nile tilapia brood after resting system (mean \pm S.E.)

\begin{tabular}{lccc}
\hline & \multicolumn{3}{c}{ Resting system } \\
\cline { 2 - 4 } & Without & In hapa & In pond \\
\hline Number of days & 60 & 60 & 60 \\
Total larvae weight/hapa, $\mathbf{g}$ & $430^{\mathrm{c}} \pm 12.25$ & $1110^{\mathrm{b}} \pm 57.70$ & $1400^{\mathrm{a}} \pm 102.55$ \\
Total larvae number/hapa & $38700^{\mathrm{c}} \pm 1103$ & $99900^{\mathrm{b}} \pm 5193$ & $126000^{\mathrm{a}} \pm 9230$ \\
Larvae weight, g/hapa/month & $215^{\mathrm{c}} \pm 6.13$ & $555^{\mathrm{b}} \pm 28.85$ & $700^{\mathrm{a}} \pm 51.28$ \\
Larvae number/hapa/month & $19350^{\mathrm{c}} \pm 551$ & $49950^{\mathrm{b}} \pm 2596$ & $63000^{\mathrm{a}} \pm 4615$ \\
Larvae weight/female & $4.78^{\mathrm{c}} \pm 0.14$ & $12.33^{\mathrm{b}} \pm 0.64$ & $15.56^{\mathrm{a}} \pm 1.14$ \\
Larvae number/female & $430^{\mathrm{c}} \pm 12.25$ & $1,110^{\mathrm{b}} \pm 57.70$ & $1,400^{\mathrm{a}} \pm 102.55$ \\
Spawning intervals, day & $94.40^{\mathrm{a}} \pm 2.73$ & $29.44^{\mathrm{b}} \pm 1.62$ & $23.53^{\mathrm{b}} \pm 1.78$ \\
Frequency spawning/female & $0.80^{\mathrm{c}} \pm 0.02$ & $2.06^{\mathrm{b}} \pm 0.11$ & $2.59^{\mathrm{a}} \pm 0.19$ \\
\hline
\end{tabular}

Values in the same row with different superscripts are significantly different $(\mathrm{P} \leq 0.05)$

Average larvae weight/female approximately $6 \mathrm{~g}$ and average larvae number $/ \mathrm{g}=90$ larva

\section{Spawning efficiency in all season:}

Reproductive performance, as indicated by larvae output per hapa or per female was enhanced in broodstock resting in hapa or pond. Mean larvae production for females rested in hapa and pond was increased by $21 \%$ and $32 \%$ than values of control in all spawning parameters as indicated in Table 4. There was a significant difference in all parameters for the benefit of brood-stock rested than control. The results showed significantly improved spawning performance with larvae collected from brood resting in pond and hapa than that collected directly from hapas without resting. This may be due to the active roles of rested males in courtship and females restore vitality, strength and production more quantity of egg. These results arein agreement with the results obtained by Lovshin and Ibrahim (1988), Ambali (1990), Little et al. (1993) and Ridha and Cruz (2003). 
Table 4. Effect of resting systems on pawning efficiency of Nile tilapia brood (mean \pm S.E.)

\begin{tabular}{lccc}
\hline & \multicolumn{3}{c}{ Resting system } \\
\cline { 2 - 4 } & Without & In hapa & In pond \\
\hline Number of days & 180 & 180 & 180 \\
Total larvae weight/hapa, $\mathbf{g}$ & $3,325^{\mathrm{b}} \pm 136.17$ & $4,010^{\mathrm{a}} \pm 103.06$ & $4,380^{\mathrm{a}} \pm 99.58$ \\
Total larvae number/hapa & $299250^{\mathrm{b}} \pm 12255$ & $360900^{\mathrm{a}} \pm 9275$ & $394200^{\mathrm{a}} \pm 8965$ \\
Larvae weight, g/hapa/month & $554.17^{\mathrm{b}} \pm 27.23$ & $668.33^{\mathrm{a}} \pm 20.61$ & $730^{\mathrm{a}} \pm 19.92$ \\
Larvae number/hapa/month & $49875^{\mathrm{b}} \pm 2451$ & $60150^{\mathrm{a}} \pm 1855$ & $65700^{\mathrm{a}} \pm 1792$ \\
Larvae weight/female & $36.94^{\mathrm{b}} \pm 1.51$ & $44.56^{\mathrm{a}} \pm 1.15$ & $48.67^{\mathrm{a}} \pm 1.11$ \\
Larvae number/female & $3325^{\mathrm{b}} \pm 136.17$ & $4010^{\mathrm{a}} \pm 103.06$ & $4380^{\mathrm{a}} \pm 99.58$ \\
Spawning intervals, day & $29.39^{\mathrm{a}} \pm 1.16$ & $24.29^{\mathrm{b}} \pm 0.59$ & $22.23^{\mathrm{b}} \pm 0.49$ \\
Frequency spawning/female & $6.16^{\mathrm{b}} \pm 0.25$ & $7.43^{\mathrm{a}} \pm 0.19$ & $8.11^{\mathrm{a}} \pm 0.18$ \\
\hline Vale
\end{tabular}

Values in the same row with different superscripts are significantly different $(\mathrm{P} \leq 0.05)$

Average larvae weight/female approximately $6 \mathrm{~g}$ and average larvae number/g $=90$ larva

The lower spawning parameters observed in the control treatment compared with two resting systems was probably caused by exhaustion of broodstock (Ridha and Cruz 1998 and Ridha et al. 1998) and by the establishment of a stronger social hierarchical structure with time in control (without resting) treatment according to Little et al. (1993) and Ridha and Cruz (2000).

\section{Economic efficiency:}

The economic efficiency of the tilapia hatcheries that applying these systems and containing 30 hapas of broodstock ( 2700 female +900 male) is presented in Table 5. The net returns from each hatchery was higher with brood-stock rested in ponds followed by brood-stock rested in hapas and the last is the control.
This study showed that if larvae collected from brood-fish rested in ponds every 5 days in a hatchery contained 3600 broodstock (30 hapa) produced about 9.460 million followed by broodstock rested in hapa 8.66 million and control 7.18 million fry after sex reversal in a spawning season. Net returns in L.E per hatchery were $115868 ; 97886$ and 66595 for the larvae collected from broodstock rest in ponds, in hapa and control, respectively. Percentages of net return to total cost were $119.45 ; 100.9$ and $70.1 \%$ for brood-stock rest in ponds, in hapa and control, respectively. The results indicate that the highest net return was obtained with the larval collecting from brood-stock rest in ponds.

Table 5. Economic efficiency of tilapia hatchery ( 30 hapa) under different resting systems

\begin{tabular}{lccc}
\hline \multirow{2}{*}{ Item } & \multicolumn{3}{c}{ Resting system } \\
\cline { 2 - 3 } Hatchery costs, L.E. & Without & In hapa & In pond \\
Brood & 20000 & 20000 & 20000 \\
Feed & 25000 & 27000 & 27000 \\
Equipment and apparatus & 25000 & 25000 & 25000 \\
Other (land, labors) & 25000 & 25000 & 25000 \\
Total costs & 95000 & 97000 & 97000 \\
Selling fry , L.E. & & & 10643400 \\
Mono sex fry & 8079750 & 9744300 & 212868 \\
Total sales & 161595 & 194886 & 115868 \\
Net returns/hatchery, L.E & 66595 & 97886 & 119.45 \\
Net returns/total costs \% & 70.10 & 100.91 & \\
\hline Pric of & & & \\
\hline
\end{tabular}

Price of 1000 fry was 20 L.E

\section{REFERENCES}

Abou-Zied, R.M. and A.A. Ali, 2007. Evaluation of Nile tilapia commercial hatcheries system in Fayoum governorate. Egypt. J. Aquat. Biol. Fish. 11 (3): 230-238.

Ambali, A.J.D. and D.C. Little, 1996. Studies on the effect of manipulating hapa size on brooodfish conditioning of Oreochromis niloticus in fertilized earthen ponds. In: Pullin, R.S.V., Lazard, J., Legendre, M., Amon Kothias, J.B., Pauly, D._Eds.., The Third International Symposium on Tilapias in Aquaculture ICLARM Conference Proceedings 41 International Center for Living Aquatic Resources Management, Manila, p. 9.
Ambali, A.J.D., 1990. Effect of hapa size on conditioning of broodstock, _Oreochromis niloticus. in fertilized earthen ponds. M. Sc. Thesis. Asian Institute of Technology, $101 \mathrm{pp}$.

AOAC, 1999. Association of Official Analytical Chemists. Official Methods of Analysis of AOAC, $16^{\text {th }}$ ed. AOAC International, Washington, DC. USA.

Bhujel, R.C., 2000. A review of strategies for the management of Nile tilapia (Oreochromis niloticus) broodfish in seed production systems, especially hapa-based systems. Aquaculture 181: 37-59.

Bhujel, R.C., D.C. Little and A. Hossain, 2007. Reproductive performance and the growth of pre- 
stunted and normal Nile tilapia (Oreochromis niloticus) broodfish in varying feeding rates. Aquaculture 273: 71-79.

Bhujel, R.C., A. Yakupitiyage, D.C. Little and W.A. Turner, 2001. Selection of a commercial feed for Nile tilapia (Oreochromis niloticus) broodfish breeding in a hapa-in-pond system. Aquaculture 194: 303-314.

Duncan, D. B., 1955. Multiple range and multiple F tests. Biometrics 11:1-42.

Eldokla, A.A., G.E. Azazy and W.A.E. Elabd, 2011. Economic study for the main factor affecting tilapia propagation activities. J. Agric. Env. Sci., vol. 10. Damanhur University, pp. 1-13.

El-Sayed, A.F.M. 2006. Tilapia culture. CAB International, Wallingford, UK. 277 pp.

El-Sherif, M. S. and A.M. EL-Feky, 2008. Effect of ammonia on Nile Tilapia (O. niloticus) performance and some hematological and histological measures. Eighth International Symposium on Tilapia in Aquaculture. Cairo, Egypt.

Escover, E.M., O.T. Salon and I.R. Smith, 1987. The economics of tilapia fingerlings production and marketing in the Philippines. Acquacult. Fish. Manag. 18: 1-13.

GAFRD 2012. General authority for fish resources development. Fishery statistic. Egyptian Ministry of Agriculture.

Little D.C., D.J. Macintosh and P. Edwards, 1993. Improving spawning synchrony in the Nile tilapia, Oreochromis niloticus. Aquaculture and Fisheries Management 24: 399-405.

Little, D.C. and G. Hulata, 2000. Strategies for tilapia seed production. In: Beveridge, M.C.M., McAndrew, B.J. (Eds.), Tilapias: biology and exploitation. Fish and Fisheries Series, 25. Kluwer Academic Publishers, Dordrecht, The Netherlands, pp. 267-326.

Little, D.C., C.K. Lin and W.A. Turner, 1995. Commercial scale tilapia fry production in Thailand. World Aquacult. 26 (4): 20-24.

Lovshin L.L. and H.H. Ibrahim, 1988. Effect of broodstock exchange on Oreochromis niloticus egg and fry production in net enclosures. In:
Pullin R.S.V., Bhukaswan T., Tonguthai K. and Maclean J.L. (eds), Proceedings of The Second International Symposium on Tilapia in Aquaculture, ICLARM Conference Proceedings 15. Department of Fisheries, Bangkok, Thailand and International Center for Living Aquatic Resources Management, Manila, Philippines, pp. 231-236.

Magid, A. and M.M. Babiker, 1975. Oxygen consumption and respiratory behaviour of three Nile fishes. Hydrobiologia 46: 359-367.

Naiel, R.A., M.G. Aamer, A.A. Ibrahim and G.E. Azazy, 2011. Economics of fry production of fish hatcheries. Zagazig J. Agric. Res. 38 (5): 13291341.

Peters, H.M., 1983. Fecundity, egg weight and oocyte development in tilapias Cichlidae, Teleostei., ICLARM Translations 2 International Center for Living Aquatic Resources Management, Manila, Philippines 28 pp.

Purdom, C.E., 1993. Genetics and fish breeding. Chapman \& Hall, London, UK.

Rana, K.J., 1986. Parental influences on egg quality, fry production and fry performance in Oreochromis niloticus_Linnaeus. and $O$. mossambicus Peters. PhD Thesis, Institute of Aquaculture, University of Stirling, UK, 295 pp.

Ridha, M.,E.M. Cruz and A.A. Al-Ameeri, 1998. Tilapia hatchery refinement and maximizing fry production. Final Report No. KISR5275, Kuwait Institute for Scientific Research, Kuwait

Ridha, M.T. and E.M. Cruz, 2003. Effect of different schedules for broodstock exchange on the seed production of Nile tilapia Oreochromis niloticus (L.) in freshwater. Aquaculture International 11, ( 3): 267-276.

Ross, L.G., 2000. Environmental physiology and energetics. In: Beveridge, M.C.M. and $\mathrm{Mc}$ Andrew, B.J. (eds) Tilapias: Biology and Exploitation .Kluwer Academic Publishers, Dordrecht/Boston/ London, pp. 89-128.

SPSS, 2007. Statistical Package For Social Science (for Windows). Release 16 Copyright (C), SPSS Inc., Chicago, USA.

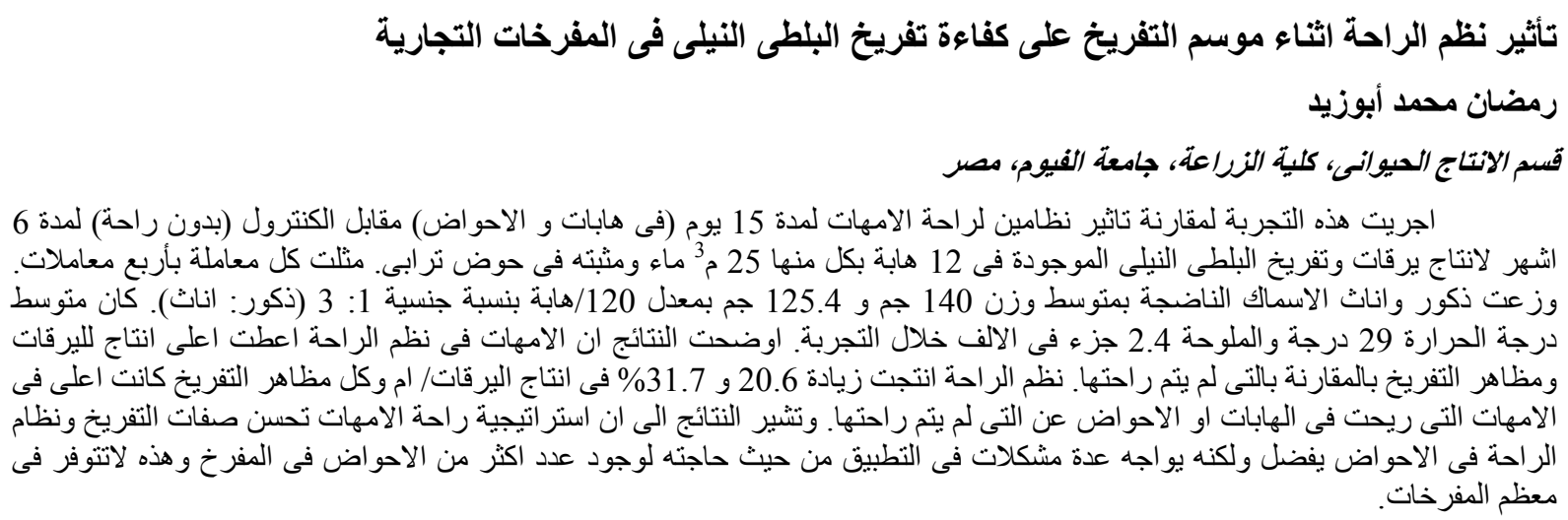

